\title{
Analysis of the antimicrobial activity of the essential oil of oregano (Origanum vulgare): a review study on the main effects on pathogens
}

Análise da atividade antimicrobiana do óleo essencial de óregano (Origanum vulgare): um estudlo de revisão sobre os principais efeitos em agentes patôgenos

Análisis de la actividad antimicrobiana del aceite esencial de orégano (Origanum vulgare): estudio de revisión de los principales efectos sobre los patógenos

Daniel Lopes Araújo

ORCID: https://orcid.org/0000-0002-1625-0368 Universidade Federal de Pernambuco, Brazil E-mail: araujodanielopes@gmail.com

Bruno Abilio da Silva Machado ORCID: https://orcid.org/0000-0003-1759-0206 Centro Universitário Maurício de Nassau Teresina, Brazil E-mail: brunnoabillio92@gmail.com

José Marcos Fernandes Mascarenhas ORCID: https://orcid.org/0000-0002-2604-4330 Cristo Faculdade do Piauí, Brazil

E-mail: zemarcosmascarenhas@gmail.com

Suzana Pereira Alves ORCID: https://orcid.org/0000-0003-1822-9762 Cristo Faculdade do Piauí, Brazil E-mail: suzaninhaalves10@gmail.com

Samilly Lorâna Farias de Sousa ORCID: https://orcid.org/0000-0003-2647-9382 Universidade Potiguar, Brazil

E-mail: samilly.lorrana@yahoo.com.br

Layanne Cavalcante de Moura

ORCID: https://orcid.org/0000-0003-2781-1076 Centro Universitário UniFacid, Brazil

E-mail: layannecavalcante@hotmail.com Beatriz Cardoso Melo

ORCID: https://orcid.org/0000-0002-3638-8815

Centro Universitário Uninovafapi, Brazil

E-mail: beatrizcmelo@outlook.com

Thiago Evencio Mendes Luz

ORCID: https://orcid.org/0000-0003-0405-6856

Centro Universitário Uninovafapi, Brazil

E-mail: thiagoevencio2705@gmail.com

Leandro Luiz da Silva Loures

ORCID: https://orcid.org/0000-0001-8863-8858

Universidade Federal de Juiz de Fora, Brazil E-mail: leandrolouresnutri@gmail.com

Joelma Maria dos Santos da Silva Apolinário

ORCID: https://orcid.org/0000-0001-9521-9432 Faculdade Maurício de Nassau, Brazil. E-mail: jo.silva00@hotmail.com

Thaysla de Oliveira Sousa

ORCID: https://orcid.org/0000-0001-9192-1099 Faculdade Estácio Ceut, Brazil

E-mail: thayslalaurentina25@gmail.com

Lucas de Carvalho Siqueira

ORCID: https://orcid.org/0000-0002-4601-6441 Centro Universitário de Patos, Brazil E-mail: lucas-carvalho64@hotmail.com

Maria Aparecida de Sousa Moura ORCID: https://orcig.org/0000-0001-5502-7401 Faculdade Maurício de Nassau, Brazil E-mail: cidocaelulu@hotmail.com 


\author{
Laísa Ribeiro Rocha \\ ORCID: https://orcid.org/0000-0002-8147-8342 \\ Centro Universitário UniFacid, Brazil \\ E-mail: laisaribrocha@gmail.com \\ Mariana Silva Souza \\ ORCID: https://orcid.org/0000-0003-1920-5367 \\ Cristo Faculdade do Piauí, Brazil \\ E-mail: marianasouza_s@hotmail.com
}

\begin{abstract}
Western medicine has been trying to use natural means for the treatment of infections caused by bacteria, in this context, it is very noticeable the great interest of therapeutic agents coming from natural products, more specifically those derived from plants. In this sense, a review of the integrative literature on the antimicrobial activity of the essential oil of oregano has been carried out. For this review of integrative literature 24 scientific articles were used. The studies showed that the essential oil of Origanum vulgare L. (Lamiaceae) has been used as an element of scientific research in laboratories as an antimicrobial strategy against innumerable types of bacteria, where its high therapeutic and antimicrobial content has been proven. The essential oil of $O$. vulgare exposes a variable range of active compounds, being the monoterpenes carvacrol and thymol the majority compounds of this essential oil, which corresponds between 80,2 and $98 \%$ of the total composition of this essential oil. In view of this, the results that were described in this review could suggest that the compounds cited have antimicrobial activity, damaging the lipidic plasma membranes, compromising the $\mathrm{pH}$ homeostasis and the balance of organic ions, preventing cell division and causing dehydration in bacterial cells.
\end{abstract}

Keywords: Essential oil; Minimum inhibitory concentration; Origanum vulgare; Antimicrobial activity.

\title{
Resumo
}

A medicina ocidental vem tentando utilizar meios naturais para o tratamento de infecções causadas por bactérias, diante desse contexto, é muito perceptível o grande interesse de agentes terapêuticos vindo de produtos naturais, mais especificadamente aqueles que são derivados de plantas. Neste sentido, objetivou-se realizar uma revisão de literatura integrativa sobre a atividade antimicrobiana do óleo essencial de orégano. Para esta revisão de literatura integrativa foram utilizados 24 artigos científicos. Os estudos evidenciaram que o óleo essencial de Origanum vulgare L. (Lamiaceae) tem sido usado como um elemento de pesquisas científicas em laboratórios como estratégia antimicrobiana contra inúmeros tipos de bactéria, onde foi comprovado o seu alto teor terapêutico e antimicrobiano. O óleo essencial de $O$. vulgare expõe uma gama variável de compostos ativos, sendo os monoterpenos carvacrol e timol os compostos majoritários deste óleo essencial, o que corresponde entre 80,2 e $98 \%$ da composição total deste óleo essencial. Diante disso, os resultados que foram descritos nessa revisão puderam sugerir que os compostos citados possuem atividade antimicrobiana, lesionando as membranas plasmáticas lipídicas, comprometendo a homeostase do pH e o equilíbrio de íons orgânicos, impedindo a divisão celular e causando desidratação nas células bacterianas.

Palavras-chave: Óleo essencial; Concentração inibitória mínima; Origanum vulgare; Atividade antimicrobiana.

\section{Resumen}

La medicina occidental ha intentado utilizar medios naturales para el tratamiento de las infecciones causadas por bacterias. En este contexto, es muy notable el gran interés de los agentes terapéuticos procedentes de productos naturales, más concretamente los derivados de las plantas. En este sentido, se ha realizado una revisión de la literatura integradora sobre la actividad antimicrobiana del aceite esencial de orégano. Para esta revisión de la literatura integradora se utilizaron 24 artículos científicos. Los estudios demostraron que el aceite esencial de Origanum vulgare L. (Lamiaceae) se ha utilizado como elemento de investigación científica en los laboratorios como estrategia antimicrobiana contra numerosos tipos de bacterias, donde se ha demostrado su alto contenido terapéutico y antimicrobiano. El aceite esencial de $O$. vulgare expone una gama variable de compuestos activos, siendo los monoterpenos carvacrol y timol los compuestos mayoritarios de este aceite esencial, que corresponde a entre el 80,2 y el $98 \%$ de la composición total de este aceite esencial. En vista de esto, los resultados que se describieron en esta revisión pudieron sugerir que los compuestos mencionados tienen actividad antimicrobiana, dañando las membranas plasmáticas lipídicas, comprometiendo la homeostasis del pH y el equilibrio de los iones orgánicos, impidiendo la división celular y causando deshidratación en las células bacterianas.

Palabras clave: Aceite essencial; Concentración mínima inhibitoria; Origanum vulgare; Actividad antimicrobiana.

\section{Introduction}

Currently, infections by pathogens such as bacteria, either in hospital environments (Araújo, 2020) or in food contamination (Reis et al., 2020) present a great risk to public health. Medicine has been seeking additional alternatives to try to contain this type of problem, where an important step is to analyze the bactericidal potential of essential oils in relation to 
bacteria and fungi. In some recent studies, these compounds have been used in several researches and have shown to be very effective when tested on microorganisms that present resistance to older drugs (Oliveira Prete et al., 2020, Drawanz et al., 2020).

Antimicrobial resistance is the development of resistance in microorganisms (bacteria, viruses, parasites, and fungi) to an antimicrobial drug to which they were previously sensitive. This resistance in a wide variety of infectious agents is a growing threat to public health, especially with the rapid worldwide spread of multidrug-resistant bacteria that cause common infections and resist treatment with existing drugs. Bacteria may contain genes that encode the production of enzymes with properties to cleave or promote structural changes in the molecule, such as betalactamases. These act by promoting hydrolysis of the betalactam derivatives, making the molecular configuration of the antibiotic unable to bind to its receptor site, the penicillin binding proteins (PBPs), making it impossible for the drug to inhibit the synthesis of the bacterial cell wall; thus, the bacteria continue its reproductive cycle normally (Who, 2016; Who, 2017).

EOs have been used for several decades in the pharmaceutical and cosmetic industries and, more recently, are being studied as flavorings, flavoring and natural preservatives by the food industries (Costa et al., 2015). In its condition of Natural antimicrobials have the potential to be used in the control of microorganisms, reducing the need for additives, controlling contamination in food and improving shelf life extension technologies to eliminate pathogens undesirable and delay product deterioration (Porto, 2018).

Essential oils (EOs) can be extracted from different parts of the same plant and, although they present similar color and appearance, they can present different chemical composition, physical-chemical characteristic and odors. Although extracted from the same organ and from the same plant species, the chemical composition of the essential oil can vary significantly according to specific seasons, and this variation can occur both in the period of a day and in seasons of the year, be related to the stage of development, to the climatic and soil conditions (Souza et al., 2019).

The essential oil (EO) has its origin in the secondary metabolism of plants, which in this context, can be extracted from its flowers, leaves, branches, bark, roots and fruits (Cui, 2019). In this process, some present volatile aromatic compositions (carvacrol, thymol, eugenol, terpinol, linalol and carvone), which are the fundamental elements for the antimicrobial action to occur. These compositions are prepared to act in differentiated types of target molecules and in the functionality of bacterial cells, so that in this way they can end up becoming antibacterial mechanisms, mainly with regard to the blocking of the synthesis of nucleic acid, alterations in the sites of the cytoplasmatic membrane and in its energetic metabolism (Lamb et al., 2020).

Origanum vulgare L. (Lamiaceae), popularly known in Brazil as oregano is one of the most used condiments in Brazil for food preparation due to its high capacity to add flavor to it. It is also used for the production of EO due to its antimicrobial properties, because it has the compounds carvacrol and thymol, which can act and have positive effects against some types of bacteria and fungi (Silva et al., 2020). The carvacrol, a substance found in the essential oil of oregano (EOO), has the capacity of permebialization of the microbial cytoplasmic membrane, this action can end up causing a loss of ATP (Barbosa et al., 2015). This is all due to the interaction power with the membrane, which can dissolve in the lipidic layer, making a kind of alignment between the fatty acid chains (Lima et al., 2017).

It is important to point out that the use of these natural extracts acquired through plants can provide an alternative because they are in most cases easy to obtain, both in nature and in the laboratory, their use presents favorable characteristics in terms of cost and because they normally do not present adverse effects, genotoxic and mutagenic to humans (Tavares, 2018; Porto, 2018).

Thus, analyzing the data obtained through a literature review, our goal is to make an analysis on the use of the essential oil of Origanum vulgare (oregano) and its antimicrobial action against infectious agents. 


\section{Methodology}

To achieve the objective, an integrative review (IR) of national and international literature was conducted with a retrospective approach on virtual platforms that make available selected collections of scientific journals. It was developed in stages recommended by Carvalho (2018): identification of the theme and research question, analysis of criteria for inclusion and exclusion of scientific articles; information to be extracted from the selected studies; evaluation of the studies included; interpretation of results and presentation of the knowledge synthesis.

Scientific articles were selected in the virtual data platforms Google Academic, Scielo, PubMed and Lilacs. The researches of these were carried out from January to December of the year 2020, in a very criterious way, through the following guiding questions: What is the essential oil of oregano, what are its aspects and what are the parameters of the antimicrobial activity developed by it?

These data were also searched using the following terminologies registered in DeCS: essential oil, minimum inhibitory concentration, Origanum vulgare and antimicrobial action. The articles were selected according to the language in which it is written, where the articles were chosen in English and Portuguese.

The articles were also obtained from the application of the following inclusion and exclusion criteria: scientific articles were selected that contemplated the subject in question, which were written in their various types of correlated research, clinical cases or case reports, cohort studies, field research, literature reviews and iconographic essays, indexed to the platforms in the period from 2015 to 2020. Articles that were not related to the subject, published before 2015, that were not written in the chosen languages, did not contain a quantitative and qualitative approach, and were duplicated in divergent databases were excluded.

\section{Results and Discussion}

The biological properties of essential oils extracted from aromatic and medicinal plants have been explored for many years and currently, the use of natural antimicrobial compounds has intensified with the purpose of being applied in food preservation, as well as being used in several studies to test their bactericidal, fungicidal, antioxidant potential and in several other parameters. The essential oils as a new antibacterial principle, due to its anti-quorum-sensing activity can be important in reducing virulence and pathogenicity of drug-resistant bacteria in vivo (Reis et al., 2020; Silva et al., 2020).

EO extracted from aromatic plants have become a source of studies for application in several experiments due to their various properties, including delaying or inhibiting microbial multiplication (Silva et al., 2020). EOO is considered very effective for inhibiting Gram negative bacteria (Reis et al., 2020, Silva et al., 2020). Because it is hydrophobic in nature and easy to accept, EOs can be easily blended and used in food processing. Thus, studies on the effectiveness of EOO against various types of bacteria become important, as a way to give alternatives in the control of pathogens in pharmacology, health and food industry (Araújo, 2016).

Carvacrol and thymol are important components present in $\mathrm{EOO}$ with bactericidal effect, as they may be able to cause the disintegration of microbial cell membrane (Trevisan et al., 2018; Cui, 2019).

Some studies on the antimicrobial action of EOO have already confirmed the effectiveness of the method. This happens because of the applications of its concentrations, pure or associated to another type of extract to colonies of bacteria results of studies of some researchers who develop researches in this parameter. The inhibitory effect on bacteria is considerably significant, reaching ( $\mathrm{p} \leq 0,05)$ (Araújo, 2016).

Camargo (2015), compared the antimicrobial activity of the EOO of Ferquima ${ }^{\circledR}$ against Escherichia coli (T. Escherich, 1885) CR 131. In a concentration of 0.06\%, the oil eliminated the strain in 10 minutes. In the study of Reis (2020), 
the bacteria was inhibited by the oil in the concentration of $1.0 \%$ to $4.0 \%$. In this study, Ferquima ${ }^{\circledR}$ essential oil totally inhibited $E$. coli in 24 hours on the 0.5 MacFarland scale, at a minimum concentration of $0.75 \%$.

Pombo (2018) suggests in his experiment that Gram-positive bacteria are more sensitive than Gram-negative bacteria to EO. This is due to the degree of structural complexity of the Gram-negative bacteria cell wall. The authors also generate a discussion regarding the use of the $\mathrm{EO}$ of clove, where it was proved in the study that the substances found in oregano present more accuracy regarding the antimicrobial activity in relation to the clove.

According to Brito and his collaborators (2020), the antimicrobial capacity of the essential oil based on Origanum vulgare (EUO), free or microencapsulated diluted with $10 \%(\mathrm{v} / \mathrm{v})$, demonstrated a lot of accuracy when tested against pathogenic bacteria (Salmonellasp., Brochothrix thermosphacta, Pseudomonas fragi, Lactobacillus plantarumee Micrococcus luteus). The free form compound was less effective in inhibiting bacterial growth, which can be attributed to increased solubility and bioavailability (Hernández et al., 2014).

In a recent study conducted by researchers in the area, CIM for C. albicans and S. schenckii was, on average, $0.3 \%$, a satisfactory result, since these agents have recognized virulence and resistance factors and are considered of importance in public health. Other authors evaluated isolated compounds of the oil in C. albicans and obtained CIM of $6.5 \mathrm{mM}$ for carvacrol and $12 \mathrm{mM}$ for eugenol. In a previous study by Cleff et al. (2017), when using Origanum vulgare oil with a high concentration of 4-terpineol and balanced proportions of thymol and carvacrol, MIC of $2.72 \mu \mathrm{g} / \mathrm{mL}-1$ was shown.

It is important to point out that the active ingredients (thymol and carvacrol), which are found in the oregano compounds, cause distortion in the physical structure of the cell, causing expansion and consequent destability in the membrane, modifying its permeability, denaturing essential enzymes, and altering the proton-motive force, through variations in $\mathrm{pH}$ and electric potential (Costa et al., 2015).

The antimicrobial activity is not only due to the presence of the essential oil substances, but to the presence of other components in lower concentrations that can promote synergistic dynamics, for example, p-cymene has no antibacterial effect if used alone, but when combined with carvacrol, it facilitates the transport of the carvacrol through the cytoplasmic membrane into the bacterial cell (Reis, 2020; Figuerêdo, 2019).

The concept of synergism has been the central theme of many discussions in phytochemistry. The interaction between essential oils may represent an alternative for the potentiality of their action, however, much still needs to be clarified (Keerthirathne et al., 2016).

The in vitro results allow the conclusion that the oil of $O$. vulgare presents bactericidal and antifungal action, but it is important to perform in vivo analyses that confirm the relationship of these results, advancing in the search for therapeutic alternatives (Keerthirathne, 2016; Abdel-Latif et al., 2020).

\section{Conclusion}

Therefore, it is perceptible the effectiveness of the essential oil as an antimicrobial agent since it has substances in its internal composition capable of making its inhibitory effect on the morphogenesis of bacteria increasingly greater.

The data presented here indicate that the EOO can be a method, be it isolated or associated, once it can make difficult the selection of bacteria and parasites resistant to other types of drugs already existing. However, new studies are needed to better elucidate the effects of this composition in vivo, aiming the development of an additional pharmacological alternative for pathogens. 


\section{References}

Abdel-Latif, H. M., Abdel-Tawwab, M., Khafaga, A. F., \& Dawood, M. A. (2020). Dietary oregano essential oil improved the growth performance via enhancing the intestinal morphometry and hepato-renal functions of common carp (Cyprinus carpio L.) fingerlings. Aquaculture, 526,735432 .

Araújo, D. L., \& Oliveira, J. L. de. (2020). Identification and analysis of bacterial presence in diagnostic imaging equipment. Research, Society and Development, 9(7), e777974711. https://doi.org/10.33448/rsd-v9i7.4711

Araujo, M. M. D., \& Longo, P. L. (2016). Teste da ação antibacteriana in vitro de óleo essencial comercial de Origanum vulgare (orégano) diante das cepas de Escherichia coli e Staphylococcus aureus. Arquivos do Instituto Biológico, 83.

Barbosa, L. N., da Silva Probst, I., Andrade, B. F. M. T., Alves, F. C. B., Albano, M., de Souza, M. D. L. R., ... \& Júnior, A. F. (2015). In vitro antibacterial and chemical properties of essential oils including native plants from Brazil against pathogenic and resistant bacteria. Journal of oleo science, 64(3), 289-298.

Brito, D. A. P., de Sousa Lima, L., Soares, B. S., \& Pinheiro, S. C. S. (2020). Atividade antimicrobiana de óleo essencial de orégano frente a sorovares de salmonella enterica com resistência a antibióticos. Brazilian Journal of Development, 6(12), 94029-94036.

Carvalho, J. F. S., Pimenta, C. A. M., \& de Oliveira, S. D. (2018). Entre a ciência e a complexidade dos novos objetos de pesquisa. A construção interdisciplinar de uma metodologia de pesquisa científica. Educação, Cultura e Comunicação, 9(18).

Cordeiro, L. V., de Figueiredo, P. T. R., de Sousa, A. P., de Andrade Júnior, F. P., da Silva Souza, H. D., Araújo, D. L., \& de Oliveira Lima, E. (2020). Association of carvacrol with ceftazidime and cefepime against Klebsiella pneumoniae. Research, Society and Development, 9(7), e264974089-e264974089.

Costa, D. C., Costa, H. S., Albuquerque, T. G., Ramos, F., Castilho, M. C., \& Sanches-Silva, A. (2015). Advances in phenolic compounds analysis of aromatic plants and their potential applications. Trends in Food Science \& Technology, 45(2), 336-354.

Cui, H., Zhang, C., Li, C., \& Lin, L. (2019). Antibacterial mechanism of oregano essential oil. Industrial Crops and Products, $139,111498$.

De Figueiredo, A. R., da Silva, L. R., \& de Morais, L. A. S. (2020). Atividade biofungicida do óleo essencial de orégano no controle in vitro de Colletotrichum gloeosporioides. In Embrapa Agrobiologia-Resumo em anais de congresso (ALICE). In: Semana Científica Johanna Döbereiner, 20, 2020, Seropédica. Inteligência artificial: a nova fronteira da ciência brasileira: impactos para a agricultura sustentável. Resumos... Seropédica: Embrapa Agrobiologia, 2020.

de Oliveira Prete, R., Serafim, R. Â., de Souza, D. D. F. M., Sakanaka, L. S., \& Yamaguchi, M. M. (2020). Caracterização e aplicação de óleo de orégano como antioxidante natural em linguiça suína frescal. Brazilian Journal of Development, 6(7), 44109-44118.

De Souza, M. A., Comin, T., Feiden, T., Fritzen, A. A., \& Chies, C. (2019). Métodos alternativos de controle microbiano.

Drawanz, B. B., da Rosa Bueno, T., Bocchese, C. A. C., Bez, F. S., \& Antunes, L. E. G. (2020). Óleos essenciais e hidrolatos de orégano e cravo-da-índia sobre o desenvolvimento micelial de Botrytis cinerea isolado de morangos. Revista Verde de Agroecologia e Desenvolvimento Sustentável, 15 (4), 341-345.

Galindo, M. V., dos Santos Paglione, I., Balan, G. C., Sakanaka, L. S., \& Shirai, M. A. (2019). Atividade antimicrobiana e antioxidante de filmes comestíveis de gelatina e quitosana adicionados de óleos essenciais. Segurança Alimentar e Nutricional, 26, e019008-e019008.

Keerthirathne, T. P., Ross, K., Fallowfield, H., \& Whiley, H. (2016). A review of temperature, pH, and other factors that influence the survival of Salmonella in mayonnaise and other raw egg products. Pathogens, 5(4), 63.

Lima, D. S. D., Lima, J. C., Calvacanti, R. M. C. B., Santos, B. H. C. D., \& Lima, I. O. (2017). Estudo da atividade antibacteriana dos monoterpenos timol e carvacrol contra cepas de Escherichia coli produtoras de $\beta$-lactamases de amplo espectro. Revista Pan-Amazônica de Saúde, 8(1), 17-21.

Pombo, J. C. P., Ribeiro, E. R., de Lima Pinto, R., \& da Silva, B. J. M. (2018). Efeito antimicrobiano e sinergístico de óleos essenciais sobre bactérias contaminantes de alimentos. Segurança Alimentar e Nutricional, 25(2), 108-117.

Porto, L. L., \& Rosa, L. R. V. D. (2018). Avaliação do potencial antimicrobiano de óleos essenciais de coentro (coriandrum sativum l.) e orégano (origanum vulgare l.) (Bachelor's thesis, Universidade Tecnológica Federal do Paraná).

Reis, J. B., de Figueiredo, L. A., Castorani, G. M., \& Veiga, S. M. O. M. (2020). Avaliação da atividade antimicrobiana dos óleos essenciais contra patógenos alimentares. Brazilian Journal of Health Review, 3(1), 342-363.

Silva, J. P. L., Duarte-Almeida, J. M., Perez, D. V., \& Franco, B. D. G. D. M. (2020). Óleo essencial de orégano: interferência da compo sição química na atividade frente a Salmonella Enteritidis. Food Science and Technology, 30, 136-141.

Tavares, L. R., de Almeida, P. P., \& Gomes, M. F. (2018). Avaliação físico-química e microbiológica de goiaba (Psidium guajava) revestida com cobertura comestível à base de O-carboximetilquitosana e óleo essencial de orégano (Origanum vulgare). Multi-Science Journal (ISSN 2359-6902), 1(13), 20-26.

Trevisan, D. A. C., Silva, A. F. D., Negri, M., Abreu Filho, B. A. D., Machinski Junior, M., Patussi, E. V., \& Mikcha, J. M. G. (2018). Antibacterial and antibiofilm activity of carvacrol against Salmonella enterica serotype Typhimurium. Brazilian Journal of Pharmaceutical Sciences, 54(1).

World Health Organization. (2016). Global Antimicrobial Resistance Surveillance System (GLASS): guide to completing the GLASS implementation questionnaire (No. WHO/DGO/AMR/2016.9). World Health Organization.

World Health Organization. (2017). Global antimicrobial resistance surveillance system (GLASS) report: early implementation $2016-2017$. 